UDC 378.147]:81'271

DOI: https://doi.org/10.31470/2415-3729-2020-11-96-113

The Future Specialist's Personality Communicative Culture:

Logically Organized and Mosaic in the Related Concepts Hierarchy

\title{
Olena Kulyk
}

Doctor of Sciences in Pedagogy, Associate Professor, Professor of the Department of Ukrainian linguistics and methods of education;

Associate Professor of the Department of professional education Hryhorii Skovoroda University in Pereiaslav (Pereiaslav)

$\triangle$ 30, Sukhomlynskoho Str., Pereiaslav, Kyiv region, Ukraine, 08401 E-mail: olenakulyk@gmail.com

ORCIDiD: https://orcid.org/0000-0001-9116-4403

ResearcheriD: AAF-6921-2019

Date of receipt of the article: April 13, 2020 Article accepted for publication: June 01, 2020

Комунікативна культура особистості майбутнього фахівця: логічно впорядковане та мозаїчне в ісрархії споріднених понять

\section{Олена Дмитрівна Кулик}

доктор педагогічних наук, доцент, професор кафедри української лінгвістики і методики навчання; доцент кафедри професійної освіти ДВНЗ «Переяслав-Хмельницький державний педагогічний університет імені Григорія Сковороди»

$\triangle$ вул. Сухомлинського, 30, м. Переяслав, Київська обл., Україна, 08401

Дата надходження статті: 13 квітня 2020 р. Стаття прийнята до друку: 01 червня 2020 р.

\section{Abstract}

The article focuses on the communicative culture of applicants for higher education formation, future specialists in various fields, which is topical for modern pedagogical science. 
The research goal is to focus the scientists' attention on the considerate, balanced and judicious interpretation of the concept of «communicative culture» in general; on the balanced formulation of pedagogical research topics related to the development of communicative culture in the future specialists with higher education in particular.

Methods. The research methods used were observation, abstraction, analysis, synthesis, induction, deduction, systematization, generalization and modeling.

The results. The conducted research allowed the author to reveal the probable reasons for scientists' different interpretations of the concept of "communicative culture»; to differentiate and logically organize the concepts, related to the mentioned above, in the context of communicative culture formation in the future specialist with higher education; to provide practical recommendations for scientists to use verbal nouns for identifying actions in the process of formulating pedagogical research topics related to the communicative culture formation in the future specialists with higher education.

Conclusions. The concept of «communicative culture» has a linguocultural background, and «communicative culture of an individual ... (teachers / applicants for higher education / future specialists in a particular field, etc.)» are of general didactic and methodological basis. The communicative culture is a part of the general culture; its formation comes in close interrelation with the culture of language, speech, virtual, information and digital cultures in the process of communicative competence formation in the future specialist with higher education. When formulating the pedagogical research topics, scientists should use the verbal noun «formation», referring to «communicative competence», and «education», «development» should be used in the terminological compounds «communicative culture education», «communicative culture development», where «education» is more motivated. 
Keywords: communicative culture, competence, applicants for higher education, pedagogical research, topic formulation, language, speech.

\section{References}

1. Hrechanivska, P.E. (2015). Kulturolohiia : terminolohichnyi slovnyk [Cultural Studies : Terminological Dictionary]. Kyiv : Natsionalna akademiia kerivnykh kadriv kultury i mystetstv [in Ukrainian].

2. Zakon Ukrainy «Pro vyshchu osvitu» vid 01.07.2014 № 1556-VII [The Law of Ukraine «On Higher Education» from 01.07.2014 № 1556-VII]. (n. d.). zakon4.rada.gov.ua. Retrieved from http://zakon4.rada.gov.ua/laws/show/1556-18 [in Ukrainian].

3. Kostyrya, I. (2019). Language and Culture in the European Integration Strategy of Ukraine. International Relations : Theoretical and Practical Aspects. 4. 176-186. Retrieved from http://international-relations.knukim.edu.ua/article/ download/177648/177495.

4. Metodychni rekomendatsii shchodo rozroblennia standartiv vyshchoi osvity [Methodological recommendations for the higher education standards creation]. (n. d.). edu-mns.org.ua. Retrieved from http://edu-mns.org.ua/img/news/8635/NakMON_1254_19. pdf [in Ukrainian].

5. Pet'ko, L., Popova, L., Kulyk, O., Kardash, L., Ovsiienko, L., Denysiuk, I., Proskurniak, O. (2020). Web Oriented Education Course Design Model in the Entrepreneurship Education System. Journal of Entrepreneurship Education. USA. (Vol. 23, pp. 1-9).

6. Slovnyk ukrainskoi movy online [Ukrainian Dictionary online]. (n. d.). services.ulif.org.ua. Retrieved from http://services. ulif.org.ua/expl [in Ukrainian].

7. Shcherbyna, D.V. (2018). Akme-oriientovana model formuvannia komunikatyvnoi kultury maibutnikh konsultantiv osvitnoi sfery u protsesi mahisterskoi pidhotovky [Acme-oriented model of communicative culture formation of future educational consultants in the process of master's training]. Teoriia ta metodyka 
profesiino-pedahohichnoi pidhotovky osvitianskykh kadriv : akmeolohichni aspekty [Theory and Methodology of Professional and Pedagogical Training of Educational Staff : Acmeological Aspects : monograph. Kyiv : Vyd-vo NPU imeni M.P. Drahomanova [in Ukraine].

\section{Вступ}

Виховання комунікативної культури майбутніх фахівців у будь-якій галузі під час їхньої професійної підготовки є одним із найважливіших завдань якісної вищої освіти у викликах сьогодення. Визначальним складником фахової діяльності $\epsilon$ спілкування, результативність якого залежить від урахування, усвідомлення і прийняття співрозмовниками певних мовних норм, правил поведінки, культурологічних цінностей одне одного й середовища, у якому відбувається перебіг комунікативної взаємодії.

Глобалізаційні й інтеграційні перетворення дали можливість розширити межі поля фахової діяльності, однак водночас зробили партнерську співдію складнішою: ділові контакти між представниками різних країн (а отже, й культур) $є$ одним із критеріїв оцінювання конкурентоздатності фахівця, організації, підприємства на ринку праці в Україні й світі; запорукою встановлення і розвитку таких контактів $є$ ділове спілкування, що, своєю чергою, вимагає від комунікантів обопільного прагнення досягти культурно-лінгвістичного паритету в комунікації.

Щоб перетворити прагнення на реальність, фахівець повинен мати ділову комунікативну практику: бути готовим і здатним спілкуватися в різних контекстах як з одним співрозмовником, так і з малою, великою групою, аудиторією; адаптувати стилі спілкування; вести перемовини в усній, письмовій, візуальній, діалоговій формах; добирати ефективні аргументи; упевнено, але 3 повагою й професіоналізмом, вступати в конструктивний i критичний діалог 3 представниками різних країн. В означеному аспекті не можна не погодитися 3 переконливим твер- 
дженням I. Костирі про те, що мова і культура, вироблення культурних цінностей у різноманітних соціокультурних контекстах є сьогодні головними пріоритетами в євроінтеграційній стратегії України (Kostyrya, 2019: 179). Саме тому проблема виховання комунікативної культури здобувачів вищої освіти, майбутніх фахівців у різних галузях, є актуальною для сучасної педагогічної науки.

Оскільки становлення поняття «комунікативна культура» відбувалося на стикові різних галузей наукового пізнання філософії, соціології, культурології, лінгвістики, теорії комунікації, теорії інформації, теорії впливу, психології, педагогіки й інших - автори значної кількості сучасних наукових праць (зокрема й дисертаційних робіт, захищених упродовж попередніх п’яти років) приділили увагу дослідженню наукової семантики поняття «комунікативна культура», 3'ясуванню його глибинної сутності, структурних складників, моделей, зовнішньо- і внутрішньосистемних зв' язків, зокрема і в аспекті формування комунікативної культури особистості: А. Аносова, Л. Варга, Л. Васильєва, Р. Вілке, О. Горошкіна, Н. Завацька, А. Ібатова, С. Караман, Ю. Козаченко, В. Корнієнко, І. Костиря, Л. Кузьменська, Б. Мантула, М. Оліяр, М. Пентилюк, М. Петрушкевич, Р. Радхіка, В. Ронг, Л. Руденко, М. Хілл, О. Хлистун, К. Губерт, О. Ясько й інші. Незважаючи на здобутки сучасних українських і зарубіжних науковців у дослідженні феномену «комунікативна культура», концептуальна неоднорідність значення його призвела до необмеженої кількості авторських потрактувань, що викликало термінологічне сум'яття й певний хаос ієрархії споріднених понять.

Мета статті - привернути увагу наукової спільноти до уважного, розсудливого потлумачення дослідниками поняття «комунікативна культура» в цілому; до виваженого формулювання тем педагогічних досліджень, пов'язаних 3 вихованням комунікативної культури майбутніх фахівців з вищою освітою зокрема. 
Завдання - унаочнити «легковажне» ставлення дослідників до потлумачення поняття «комунікативна культура» й обгрунтувати ймовірні причини; диференціювати та логічно впорядкувати поняття, споріднені з означеним, у контексті виховання комунікативної культури майбутнього фахівця 3 вищою освітою; дати практичні рекомендації щодо послуговування науковцями конструкціями з віддієслівними іменниками на позначення дій у процесі формулювання тем педагогічних наукових досліджень, пов'язаних з вихованням комунікативної культури майбутніх фахівців з вищою освітою.

\section{Матеріал і методи досліджень}

Матеріалом для наукової рецепції слугували особисті спостереження та результати критичного опрацювання науковоаналітичних матеріалів українських і зарубіжних учених стосовно до аналізу поняття «комунікативна культура», що дало змогу логічно впорядкувати споріднені з ним, окреслити їхню ієрархію в аспекті проблеми виховання комунікативної культури особистості майбутнього фахівця з вищою освітою (без урахування конкретного фаху), дати практичні рекомендації щодо формулювання тем педагогічних наукових досліджень, пов'язаних 3 вихованням комунікативної культури майбутніх фахівців у різних галузях.

У дослідженні було використано методи спостереження, абстрагування, аналізу, синтезу, індукції, дедукції, систематизації, узагальнення, моделювання.

\section{Результати та їхне обговорення}

Останнім часом натрапляємо на значну кількість наукових студій, у яких дослідники широко тлумачать поняття «комунікативна культура» й активно послуговуються ним. Проаналізувавши дефініції, пропоновані науковцями у галузі філософії, педагогіки, психології, лінгводидактики, культурології ми мали змогу переконатися у відсутності єдиного тлумачення цього феномену, що зумовлено наявністю різних підходів до його вивчення, дискусійністю, багатогранністю й, що 
надзвичайно важливо, значною кількістю споріднених понять, через які дослідники намагаються розкрити сутність його, або ж, навпаки, через поняття «комунікативна культура» розкрити сутність споріднених. Це призводить до плутанини й розмиває межі досліджуваного феномена, що для педагогічної науки $\epsilon$ неприйнятним, адже під час навчання здобувачів освіти педагог має усвідомлювати суть, місце, значущість, послідовність, підпорядкування, безпосередній чи опосередкований зв'язок, кожної «ланки» (категорій і понять) того «ланцюжка» (процесу навчання), що уможливлює досягти бажаних результатів у підготовці висококваліфікованих фахівців у тій чи тій галузі. Студіюючи ж сучасні наукові здобутки, ми фіксуємо «легковажне» / «вільне» поводження дослідників з тлумаченням означеного поняття, що свідчить про не усвідомлене, а фрагментарне його розуміння. Проілюструємо це на прикладах.

Уважаємо за потрібне зауважити, що одне із завдань нашої рецепції передбачало унаочнити «легковажне» ставлення дослідників до потлумачення поняття «комунікативна культура» й обгрунтувати ймовірні причини, а 쓰 здійснити огляд їхніх наукових здобутків. Задля того, щоб не перевантажувати нашу рецепцію надмірною кількістю джерел, ми вважали за доцільне зреалізувати означене завдання з опертям на одну (але грунтовну) працю «Акме-орієнтована модель формування комунікативної культури майбутніх консультантів освітньої сфери у процесі магістерської підготовки», що слугувала розділом колективної монографії «Теорія та методика професійно-педагогічної підготовки освітянських кадрів: акмеологічні аспекти». Авторка наукової студії - Д. Щербина - здійснила ретельний огляд наукових праць (41 джерело), що стосуються досліджуваної проблеми, навела прямі й непрямі цитати науковців, з опертям на які ми спробуємо поставити низку запитань, що вимагають відповіді (Табл. 1). Для прикладу наведемо цитати 3 кількох, проаналізованих дослідницею джерел. 
Таблиця 1

\section{Тлумачення й інтерпретація поняття "комунікативна культура»} (з опертям на розвідки науковців, проаналізовані Д. Щербиною)

\begin{tabular}{|c|c|}
\hline $\begin{array}{c}\text { Тлумачення } \\
\text { поняття "комунікативна культура" } \\
\text { (цитати науковців з опертяи на дослідження } \\
\text { Д. Щербини) }\end{array}$ & $\begin{array}{c}\text { Iнтерпретація } \\
\text { (запитання, цо биникають б процесі } \\
\text { інтерпретації тлумиачень) }\end{array}$ \\
\hline $\begin{array}{l}\text {... сукупність ціннісних структур у вигляді емоційної } \\
\text { або моральної культури, культури мислення й культури } \\
\text { мови, які, в свою чергу, є інваріантними компонентами } \\
\text { структури діяльності, що забезпечують систему } \\
\text { iнваріантно діяльістих якостей особистості } \\
\text { (В. Ледньов) (Щербина, 2018: 453) }\end{array}$ & $\begin{array}{l}\text { тобто: } \\
\text { - комунікативна культура - уе } \\
\text { сукупність іниих видів, зокрема } \\
\text { емочійной, моральной, культури } \\
\text { мислення й мови? } \\
\text { - складник діяльності? }\end{array}$ \\
\hline 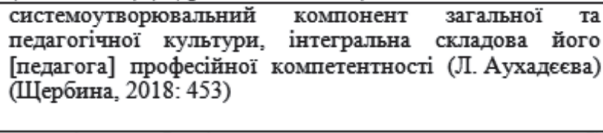 & $\begin{array}{l}\text { тобто: } \\
\text { - комунікативна культура - складник } \\
\text { загальної і педагогічної культури? } \\
\text {-у яких взаємозв'язках перебувають } \\
\text { загальна й педагогічна культура? }\end{array}$ \\
\hline $\begin{array}{l}\text { динамічне особистісне утворення, що концентрує у собі } \\
\text { мистецтво мовлення і слухання, об'єктивне сприймання } \\
\text { i правильного розуміння учня, сприяє побудові } \\
\text { гуманних стосунків і досягненню ефективної взаємодіі } \\
\text { на основі спільних інтересів (В. Садова) (Щербина, } \\
2018: 453 \text { ) }\end{array}$ & $\begin{array}{l}\text { mобто: } \\
\text { - комунікативна культура }=\text { (тобто } \\
\text { те саме, чо) мовленнєва діяльність } \\
\text { (адже саме вона передбачає } \\
\text { аудіюванн, говорінн, читання й } \\
\text { письмо)? }\end{array}$ \\
\hline $\begin{array}{l}\text { являє собою систему знань, норм, цінностей і образів } \\
\text { поведінки, прийнятнх у суспільстві, і вміння органічно, } \\
\text { природно і невимушено реалізовувати іх у діловому та } \\
\text { емоційному спілкуванні (А. Мудрик) (Щербина, 2018: } \\
\text { 453) }\end{array}$ & $\begin{array}{l}\text { mобто: } \\
\text { - комунікативна культура-че знання } \\
\ldots \quad i \text { вміння їх реалізовувати у } \\
\text { спілкуванні? }\end{array}$ \\
\hline $\begin{array}{l}\text { єдність ціннісних структур у сукупності культури мови, } \\
\text { культури вербального спілкування, емоційної культури, } \\
\text { культури мислення, культури взаємодії (С. Ітнатьєва) } \\
\text { (Щербина, 2018: 454) }\end{array}$ & $\begin{array}{l}\text { тобто: } \\
\text { - комунікативна культура - уе } \\
\text { сукупність іниих, зокрема емочійної, } \\
\text { культури мислення, взаєодій? }\end{array}$ \\
\hline 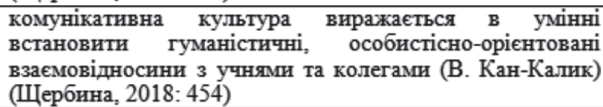 & $\begin{array}{l}\text { тобто: } \\
\text { - комунікативна культура - уе уміння } \\
\text { встановити взаємовідносини? }\end{array}$ \\
\hline $\begin{array}{l}3 \text { одного боку, - специфічний спосіб людської } \\
\text { діяльності, спосіб діяльності педагога, з іншого-процес } \\
\text { самореалізаціі особистості педагога (Ю. Ушачева) } \\
\text { (Щербина, 2018: } 455 \text { ); } \\
\epsilon \text { засобом створення внутрішнього світу особистості } \\
\text { (Ю. Ушачева) (Щербина, 2018: 455) }\end{array}$ & $\begin{array}{l}\text { тобто: } \\
\text { - комунікативна культура - че спосіб } \\
\text { ділльності? } \\
\text { - прочес самореалізаиіi? } \\
\text { - засіб? }\end{array}$ \\
\hline $\begin{array}{l}\text { в основі комунікативної культури лежить загальна } \\
\text { культура особистості (І. Мазаєва) (Щербина, 2018: 456); } \\
\text { у структурі загальної культури особистості професійна } \\
\text { комунікативна культура відображається в таких } \\
\text { компонентах, як культура саморегуляціі, культура } \\
\text { інтелектуальної діяльності і власне культура мовної } \\
\text { поведінки (І. Мазаєва) (Щербина, 2018: 456) }\end{array}$ & $\begin{array}{l}\text { mобто: } \\
\text { - комунікативна культура } \\
\text { складником загальної? } \\
\text { - комунікативна культура - уе } \\
\text { сукупність інших, зокрема культури } \\
\text { саморегуляуії, інтелектуальної } \\
\text { діяльності, мовної поведінки? }\end{array}$ \\
\hline
\end{tabular}

3 незначної кількості наведених тлумачень можемо висновковувати про:

1. Різноаспектність у потрактуванні досліджуваного поняття, що, своєю чергою, призводить до безладу, браку організованості, системності, незлагодженості в усвідомленні й використанні складників 
понятійно-категорійного апарату педагогічної науки. Причину вбачаємо в тому, що поняття не отримало більш-менш усталеного тлумачення, оскільки не набуло статусу «педагогічного явища», хоча активно використовується в наукових студіях і науково-педагогічній діяльності викладачів.

2. Відсутність вдумливого i серйозного аналізу поняття «комунікативна культура», що призводить до ототожнення йогозіншими, міждисциплінарними (у пропонованих прикладах: засіб, спосіб, знання, вміння, процес, складник діяльності, мовленнєва діяльність, структура, єдність структур тощо). Імовірна причина: міждисциплінарний аспект зумовлює «кругообіг» (перехресні покликання) термінопонять, матеріальною оболонкою яких є слова, що, своєю чергою, можуть слугувати іншими поняттями - це часто призводить до багатозначності, неясності, неточності під час формулювань умовиводів дослідників. Саме тому необхідно скрупульозно з'ясовувати значення слів, щоб уживати їх в строго визначеному сенсі в аспекті досліджуваної проблеми.

3. Неаргументоване потлумачення поняття одного різновиду культури через інші, що, на нашу думку, зумовлено відсутністю єдиної класифікації різновидів культури, опису їхніх взаємозв'язків i підпорядкування. До прикладу, під час аналізу наукових джерел (словників, довідників, енциклопедій, монографій, наукових та науково-методичних статей тощо) ми натрапляли на потлумачення таких різновидів культури: загальна, професійна (фахова), національна, гендерна, естетична, моральна, матеріальна, інформаційна, цифрова, віртуальна, мислення, мовлення, мови, художня, комунікативна, екологічна, елітарна, інтелектуальна, політична, приватна, корпоративна, повсякденна, релігійна, регіональна, світова, семіотична, традиційна, управління, управлінського рішення, народна, моральна, міжнаціональних відносин, масова, локальна, життєзабезпечення, етнічна, духовна, елітарна, автохтонна й багато інших. Імовірна причина: культура - складний і динамічний феномен, що зазнає постійних змін, конкретизується й розгалужується в різних напрямах, кількість яких постійно збільшується (лише в одному термінологічному словникові нараховуємо їх аж 32 (Гречаніська, 2015)), відсутність упорядкування призводить до плутанини та довільного потрактування їх. 
На наше переконання, поняття «комунікативна культура» має, насамперед, лінгвокультурологічне підгрунтя. Тому в дослідженні тлумачимо ії як сферу загальної культури, у межах якої відбувається иілеспрямований інформачійний обмін між двома й більше особами за допомогою різних знакових систем, щзо дає змогу орієнтуватися y певному соціокультурному середовищі, упорядковувати власну життєдіяльність, передбачати ї̈ наслідки, обирати той чи той тип, манеру й форму спілкування.

Що стосується педагогічних досліджень, науковці послуговуються терміном «комунікативна культура особистості ... (педагогів / здобувачів освіти / майбутніх фахівців у певній галузі)», який має загальнодидактичне і спщіальнодидактичне (методичне) підгрунтя.

У межах нашого дослідження мова йде про комунікативну культуру особистості здобувачів вищої освіти - майбутніх фахівців будь-якої галузі, а отже, необхідним є опертя на реалізацію компетентнісного підходу до навчання. Упродовж навчання в закладі вищої освіти здобувачі мають оволодіти певними компетентностями (іхньою множиною), обов'язковий перелік яких визначено в Стандартах вищої освіти, що «розробляються для кожного рівня вищої освіти в межах кожної спеціальності відповідно до Національної рамки кваліфікацій (НРК)» (Закон України, 2014), (Методичні рекомендації, 2019). Визначені Стандартами загальні та фахові компетентності конкретизовано-деталізовані 3 огляду на відповідну спеціальність, однак чіткої межі не мають, оскільки взаємопов'язані іє складниками інтегральної. Якщо ж абстрагуватися від деталізації компетентностей, натомість згрупувати їх за істотними ознаками поза межами конкретного фаху, то можемо виокремити ключові для віддзеркалення компетентнісної моделі випускника будь-якої спеціальності: фахова, комунікативна, інформаційна, прагматична, соціокультурна / соціолінгвістична. У процесі формування тієї чи тієї компетентності викладач, на нашу думку, має забезпечити й виховання в майбутніх фахівців різних видів культури. Для унаочнення наших умовиводів використаємо схему. Оскільки компетентнісна модель випускника ЗВО, майбутнього фахівця у певній галузі, має мережеву структуру, у схемі віддзеркалено лише той сегмент, що об'єднує формування компетентностей із вихованням різних видів культури, 
продемонстровано місце комунікативної культури в цьому сегменті та взаємозв’ язок зі спорідненими поняттями (Рис. 1).

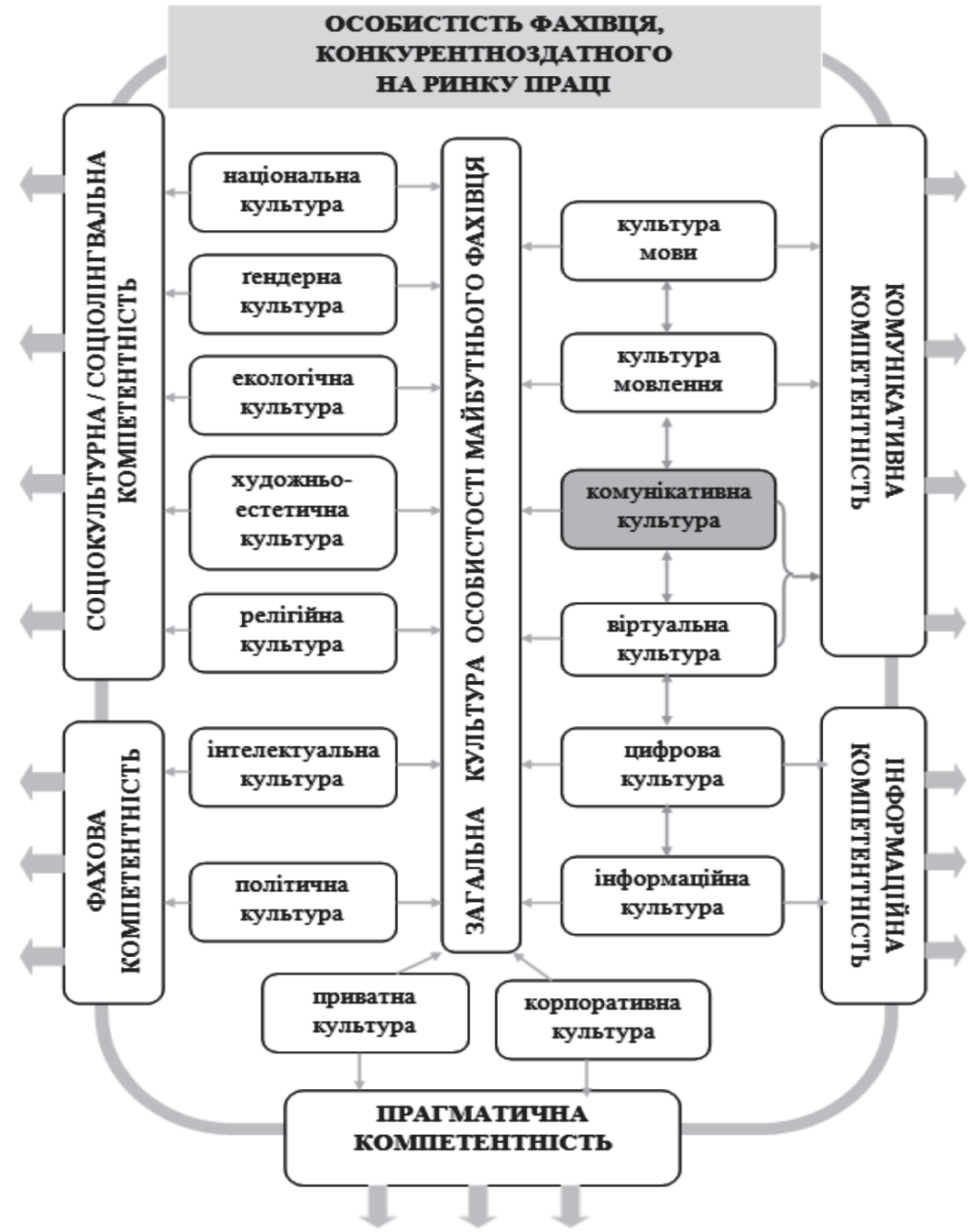

Рис 1. Фрагмент компетентнісної моделі випускника ЗВО: сегмент, що об'єднує формування компетентностей майбутнього фахівця з вихованням різних видів культури 
Як бачимо, виховання комунікативної культури (яка, своєю чергою, є складником загальної) викладач має забезпечити у процесі формування комунікативної компетентності особистості майбутнього фахівця з вищою освітою в тісному взаємозв'язку з культурою мови (фахівець має дотримуватися мовних норм); культурою мовлення (майстерно послуговуватися мовно-виражальними засобами з урахуванням мети й обставин, у яких відбувається перебіг комунікації); віртуальною культурою (дотримуватися правил мережевої поведінки під час віртуального спілкування); інформаційною (грамотно формулювати власні інформаційні потреби й запити, вести інформаційнокомунікаційний діалог), циифровою (використовувати інструменти цифрових комунікацій для отримання та поширення інноваційних знань). Неабияку роль у цьому відіграє педагогічно продумане використання веб-орієнтованих технологій для забезпечення досягнення дидактичних цілей (див: Pet'ko \& Popova \& Kulyk \& Kardash \& Ovsiienko \& Denysiuk \& Proskurniak, 2020).

3 огляду на те, що виховання комунікативної культури майбутнього фахівця з вищою освітою тісно пов'язане з іншими складниками його загальної культури й має бути зреалізоване в процесі формування комунікативної компетентності, маємо закцентувати увагу на формулюванні тем педагогічних наукових студій, пов'язаних із досліджуваною проблемою. За нашими спостереженнями, численна кількість праць має схожі формулювання, як-от: «Формування комунікативної культури...» й далі майбутнього фахівия медччного профілю, сфери обслуговування, економіста, юриста, студентів технічних закладів освіти, вчителя музики й т. ін. Або ж «Розвиток комунікативної культури...» й далі те саме, або «Виховання комунікативної культури...» й далі те саме. Оскільки досягнення високого професійного рівня аксіоматично передбачає ознайомлення фахівця з сучасними науковими дослідженнями у певній науковій галузі (чи й проведення власних), виховуючи в здобувачів вищої освіти комунікативну культуру, викладач має посилити увагу до слова, його значення, зокрема в наукових дослідженнях.

Зазначене вище спонукало нас звернутися до тлумачних словників, у яких віддзеркалені не лише загальновживані значення 
лексем, а й термінні, для фіксації яких, окрім мовознавців, залучають і фахівців у певній галузі. Розглянемо значення дієслів «формувати», «виховувати», «розвивати» 3 опертям на тлумачний словник української мови (Словник української мови online) (Табл. 2).

Таблиця 2

Значення діссліб "формубати", "бихобубати", "розбияати" б тлумачному словникові української моби

\begin{tabular}{|c|c|}
\hline C7060 & Значення \\
\hline Формувати & 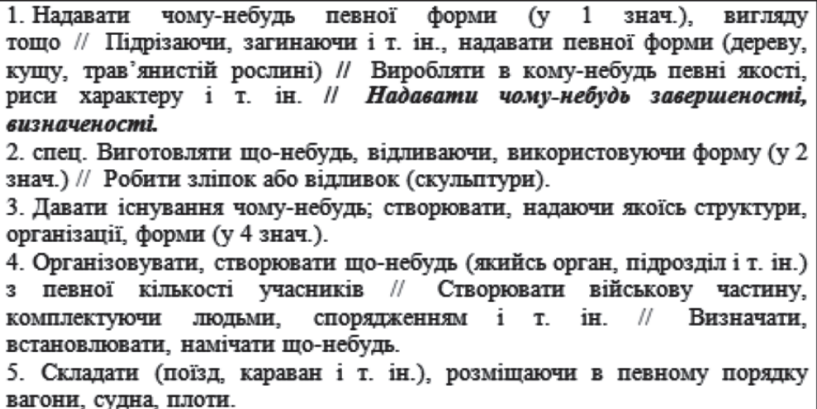 \\
\hline Виховувати $^{1}$ & 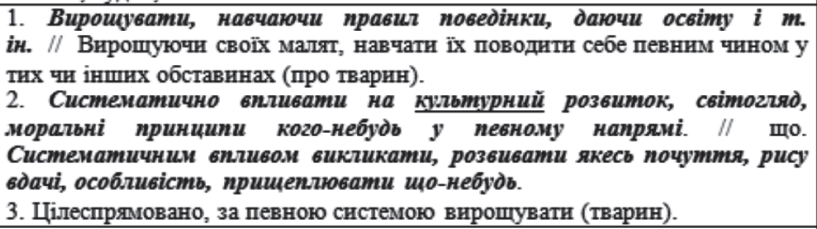 \\
\hline Розвивати & 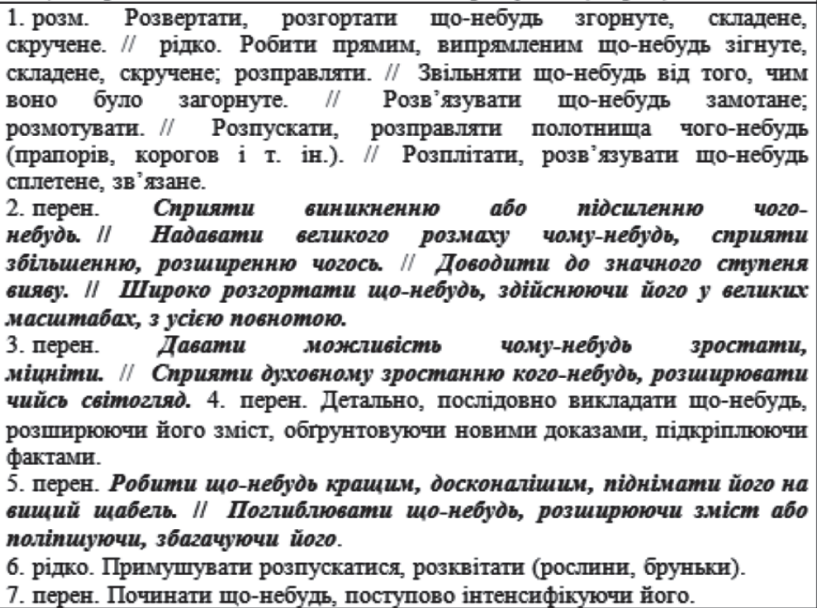 \\
\hline
\end{tabular}


У таблиці напівжирним курсивом ми виокремили ті значення, які, на нашу думку, слугують підгрунтям у потрактуванні педагогічних понять, що містять означені дієслова.

Аналіз значення лексеми «формувати» - надавати чому-небудь завершеності, визначеності - спонукає нас висновковувати, що вживання віддієслівного іменника «формування» у поєднанні з поняттям «культура» в синтаксичній конструкції «формування культури» не $є$ вмотивованим у формулюванні тем педагогічних рецепцій, оскільки, формування передбачає наявність певного результату який можна виміряти. Чи можна виміряти «завершеність», «визначеність» культури? Уважаємо, що ні. Однак вживання означеного віддієслівного іменника умотивоване в синтаксичних конструкціях у формулюванні тем на зразок «Формування ... компетентності...», адже «завершеність», «визначеність» іiі в здобувачів вищої освіти можна виміряти з опертям на визначені освітньою програмою очікувані результати навчання.

Аналіз значення лексем «виховувати», «розвивати» дає підстави для висновків, що вживання віддієслівних іменників «виховання», «розвиток» у синтаксичних конструкціях під час формулюванні тем на зразок «Виховання / Розвиток ... культури...» $\epsilon$ вмотивованим, оскільки не передбачають вимірювання і1і. Наприклад, дієслово «розвивати» в значенні робити щзо-небудь кращим, досконалішим не вказує на завершеність дії (виміряти досконалість неможливо), лише окреслює рух у цьому напрямі. Найбільш обгрунтованим і промовистим у формулюванні тем педагогічних досліджень, пов'язаних з культурою, зокрема й комунікативною, майбутніх фахівців, уважаємо дієслово «виховувати», а точніше - віддієслівний іменник «виховання», у значенні систематично впливати на культурний розвиток, світогляд, моральні принципи кого-небудь у певному напрямі.

Підсумовуючи зазначимо, що аналіз семантики дієслів та утворених від них іменників, що ними послуговуються дослідники у процесі формулювання тем педагогічних досліджень, пов'язаних iз комунікативною культурою майбутніх фахівців з вищою освітою, засвідчив: віддієслівний іменник «формування» варто вживати у 
термінологічному сполученні «формування ... компетентності», а «виховання», «розвиток»- у сполученнях «виховання ... культури», «розвиток ... культури», причому перше більш умотивоване. Тому науково обгрунтованим вважаємо формулювання тем, на зразок: «Виховання комунікативної культури майбутнього вчителя української мови і літератури у процесі формування комунікативної (чи іншої) компетентності» або ж «Формування інформаційної (чи іншої) компетентності майбутніх фахівців у сфері обслуговування засобами виховання комунікативної культури» тощо.

\section{Висновки}

Проведене дослідження уможливило дійти таких висновків:

1. Поняття «комунікативна культура» $\epsilon$ міждисциплінарним, однак, передовсім, має лінгвокультурологічне підгрунтя. У дослідженні тлумачимо іï як сферу загальної культури, у межах якої відбувається цілеспрямований інформаційний обмін між двома й більше особами за допомогою різних знакових систем, що дає змогу орієнтуватися у певному соціокультурному середовищі, упорядковувати власну життєдіяльність, передбачати іiі наслідки, обирати той чи той тип, манеру й форму спілкування. Поняття «комунікативна культура особистості ... (педагогів / здобувачів освіти / майбутніх фахівців у певній галузі тощо)» має загальнодидактичне і спеціально дидактичне (методичне) підгрунтя.

2. Комунікативна культура є складником загальної; виховання iii викладач має забезпечити у процесі формування комунікативної компетентності особистості майбутнього фахівця 3 вищою освітою. Виховання комунікативної культури майбутнього фахівця відбувається в тісному взаємозв'язку з культурою мови, мовлення, віртуальною, інформаційною й цифровою; з іншими різновидами має взаємозв’язок у розрізі їхньої приналежності до загальної культури.

3. Аналіз семантики дієслів «формувати», «виховувати», «розвивати» засвідчив, що під час формулювання тем педагогічних досліджень науковцям варто послуговуватися віддієслівним іменником «формування», коли мовиться про компетентність 
(наприклад, формування комунікативної компетентності), а «виховання», «розвиток» - у термінологічних сполученнях «виховання культури», «розвиток культури» (наприклад, виховання комунікативної культури; розвиток комунікативної культури), причому перше - виховання -більш умотивоване. Тому науково обгрунтованим вважаємо формулювання тем, на зразок: «Виховання комунікативної культури майбутнього вчителя української мови і літератури у процесі формування комунікативної (чи іншої) компетентності» або ж «Формування інформаційної (чи іншої) компетентності майбутніх фахівців у сфері обслуговування засобами виховання комунікативної культури» тощо.

\section{Література}

1. Kostyrya I. Language and Culture in the European Integration Strategy of Ukraine. International Relations : Theory and Practical, 2019. Volume 4. P. 176-186. URL: http://international-relations. knukim.edu.ua/article/download/177648/177 495.

2. Pet'ko L., Popova L., Kulyk O., Kardash L., Ovsiienko L., Denysiuk I., Proskurniak O. Web Oriented Education Course Design Model in the Entrepreneurship Education System. Journal of Entrepreneurship Education. USA. 2020. Volume 23, Special Issue 1. P. 1-9.

3. Гречанівська П.Е. Культурологія : термінологічний словник. Київ : Національна академія керівних кадрів культури і мистецтв, 2015. 439 с.

4. Закон України «Про вищу освіту». URL: http://zakon4.rada. gov.ua/laws/

show/1556-18 (Дата звернення 05.03.2020).

5. Методичні рекомендації щодо розроблення стандартів вищої освіти. URL: http://edu-mns.org.ua/img/news/8635/ NakMON_1254_19.pdf (Дата звернення 25.03.2020).

6. Словник української мови online. URL: http://services.ulif. org.ua/expl (Дата звернення 05.03.2020).

7. Щербина Д.В. Акме-орієнтована модель формування комунікативної культури майбутніх консультантів освітньої 
сфери у процесі магістерської підготовки. Теорія та методика професійно-педагогічної підготовки освітянських кадрів : акмеологічні аспекти : монографія / керівн. авт. кол. Н.В. Гузій. Київ : Вид-во НПУ імені М.П. Драгоманова, 2018. С. 446-482.

Кулик О. Д.

Комунікативна культура особистості майбутнього фахівця: логічно впорядковане та мозаїчне в ісрархії споріднених понять

\section{Анотація}

В статті унаочнено різноаспектне ставлення дослідників до потлумачення поняття «комунікативна культура» й обгрунтовано ймовірні причини; диференційовано та логічно впорядковано поняття, споріднені з означеним, у контексті виховання комунікативної культури майбутнього фахівця з вищою освітою; надано практичні рекомендації щодо послуговування науковцями конструкціями з віддієслівними іменниками на позначення дій у процесі формулювання тем педагогічних наукових досліджень, пов'язаних 3 вихованням комунікативної культури майбутніх фахівців з вищою освітою.

Ключові слова: комунікативна культура, компетентність, здобувачі вищої освіти, педагогічні дослідження, формулювання теми, мова, мовлення.

Кулик Е. Д.

Коммуникативная культура личности будущего специалиста: логично организованное и мозаичное в иерархии родственных понятий

\section{Аннотация}

В статье проиллюстрирована разноаспектность исследовательских толкований понятия «коммуникативная культура» и 
обоснованы вероятные причины; дифференцированны и логически упорядочены понятия, родственные с указанным, в контексте воспитания коммуникативной культуры будущего специалиста с высшим образованием; даны практические рекомендации по использованию учеными конструкций с отглагольными существительными для обозначения действий в процессе формулирования тем педагогических научных исследований, связанных с воспитанием коммуникативной культуры будущих специалистов с высшим образованием.

Ключевые слова: коммуникативная культура, компетентность, соискатели высшего образования, педагогические исследования, формулировка темы, язык, речь. 